American Journal of Infectious Diseases 6 (3): 75-88, 2010

ISSN 1553-6203

(C) 2010 Science Publications

\title{
Health Impacts Estimation of Mineralogical and Chemical Characterization of Suspended Atmospheric Particles over the East Desert
}

\author{
${ }^{1}$ U. Ali Rahoma and ${ }^{2}$ Elsayed Emara \\ ${ }^{1}$ Department of Radiology, Faculty of Medical Technology, \\ Omer El- Mukhtar University, Tobruk, Libya \\ ${ }^{2}$ Department of Physiology, Faculty of Medicine, Tobruk, Libya
}

\begin{abstract}
Problem statement: The small size fraction of aerosols, measured as $\mathrm{PM}_{10}$ and $\mathrm{PM}_{2.5}$, rather than the larger particles, is considered to be responsible for most of the health effects. Such particles have a relatively long residence time in the atmosphere and can therefore travel over long distances. Hence, a large portion of ambient concentrations of $\mathrm{PM}_{10}$ and in particular of particles with an aerodynamic diameter less than $2.5 \mu \mathrm{m}\left(\mathrm{PM}_{2.5}\right)$, can be attributed to long range trans boundary air pollution or to other remote sources. The estimates of exposure and of health effects are based on a number of uncertain assumptions and data sets, as described in previous article. Approach: In industrialized Middle East countries, the daily deposition of $\mathrm{PM}_{10}$ particles in the lungs is roughly 250 $\mu \mathrm{g}$ day $^{-1}$, which represents a small dose in terms of traditional toxicology studies. Studies of $\mathrm{PM}_{10}$ have considered this total material but have not asked how much its chemical or physical characteristics contribute to its total toxicity. Results: This article focuses on the description of the present knowledge on $\mathrm{PM}_{10}$ concentration fields and predominant sources contributing to $\mathrm{PM}_{10}$ from long range transport of pollution. $\mathrm{PM}_{10}$ is a complex mixture of many known and unknown components; therefore, a short introduction on the composition of $\mathrm{PM}_{10}$ is given. The studies denote to the African dust from mean $\mathrm{PM}_{10}$ levels background levels are still 5-10 $\mathrm{mg} \mathrm{m}^{3}$ higher in the Eastern Basin (EMB) when compared with those in the Western (WMB), mainly due to the higher anthropogenic and sea spray loads. Conclusion: As regards for the seasonal trends, these are largely driven by the occurrence of African dust events, resulting in a spring-early summer maximum over the EMB and a clear summer maximum in the WMB, although in this later region the recirculation of aged air masses play an important role. Furthermore, a marked seasonal trend is still evident when subtracting the African dust load. This is characterized by a high summer maximum (driven by low precipitation, high isolation) and a winter minimum (intense synoptic winds).
\end{abstract}

Key words: Health effects, Sharav Cyclone (SC), Cold Depression (CD), mineralogical characteristics, chemical characterization, Eastern Basin (EMB), x-ray icroanalysis system, Regional Background (RB), atmospheric particles, anthropogenic pollution

\section{INTRODUCTION}

Atmospheric mineral dust contains material produced by weathering of rocks and soils at the surface which undergo mobilization into the atmosphere by strong surface winds and convection that creates vertical turbulent mixing and then is carried over long distances. The major and most persistent sources of dust in the Northern Hemisphere are located in the "dust belt" that extends from $20-30^{\circ} \mathrm{N}$ and have developed under the subtropical high-pressure subsidence. The conventional wisdom is that most of the atmospheric dust is deflated from topographical lows (Sonibare, et al., 2005; Geraopoulos, et al., 2005). Nevertheless, recently it has been argued that dust originates from sand fields near these topographic lows and that approximately $50 \%$ of the total atmospheric dust mass originates from disturbed soils. The hundred and fifty million tons out of the one billion tones of dust originating from North Africa are transported to the Mediterranean basin. The major synoptic systems that bring desert dust from the Arabian and Saharan deserts in the spring, fall and winter to the east Mediterranean are Red Sea trough (RS), Sharav Cyclone (SC) and

Corresponding Author: U. Ali Rahoma, Department of Radiology, Faculty of Medical Technology,

Omer El- Mukhtar University, Tobruk, Libya Tel: +218-92-5358557 
Cold Depression (CD). The geographical location of Libya between the North African and Arabian deserts and the Mediterranean climate zones makes it vulnerable also to aerosols from European sources. In the summer, when Persian Gulf trough (PT) synoptic system dominates, it has been shown that the lower troposphere in the East Mediterranean region receives substantial amounts of atmospheric pollutants from European sources Dayan and Levy, 2005; Erel et al., 2007). Red Sea trough is an extension of a low surface pressure from a tropical depression toward the Red Sea, which sometimes penetrates north as far as Turkey and migrates along a mostly North- South direction. Sharav cyclone is a thermal low, which is enhanced by vigorous boundary level baroclinicity caused by the steep thermal gradient existing between the heated land and the cold Mediterranean Sea. Cold depressions (or also called mid-latitude cyclones) are disturbances of the polar front, which extent southward. Sometimes the $\mathrm{CD}$ has a rather southerly track and the steep pressure gradient passes over the North African coast deflating large amounts of dust and sand (Ganor and Mamane, 1982). RS storms carry dust from eastern to southeastern sources (i.e., Saudi Arabia), while during SC and $\mathrm{CD}$ the dust sources are in the south, south-west to west (i.e., North Africa). Sahara originated dust storms often have higher dust loads and occur in deeper atmospheric layers for longer periods of time relative with Arabian dust (Dayan et al., 1991). In the summer the Persian Gulf trough synoptic system (PT) prevails in the east Mediterranean. This system is a surface thermal barometric trough which is confined to the shallow atmospheric layers (up to about $1000 \mathrm{~m}$ AMSL). This system carries cool and humid air masses onshore causing a persistent elevated marine inversion. The PT is capped by a much warmer and subsiding dry air of a subtropical high-pressure system centered over North Africa and the Middle East. Persian trough is sorted into two modes (shallow and deep) according to the surface pressure gradient between Nicosia (Cyprus) and Cairo (Egypt) and their associated thermal inversion base heights (Rahoma and Hassan, 2010; Rahoma, 2010; Dayan et al., 2002). Evidence for the association between certain synoptic conditions and air pollution episodes over the East Mediterranean (Dayan and Levy, 2005; Behnert, et al., 2007) led us to adopt similar synoptic categorization in the current study. Meteorological analyses were combined with chemical and mineralogical characterization of suspended desert dust and aerosols during the synoptic conditions outlined above. This study focuses on the inorganic, "mineral" fraction (represented by the concentrations of $\mathrm{Al}, \mathrm{Ca}, \mathrm{Mg}, \mathrm{Si}$ ) of the aerosols. According to the conventional wisdom this fraction represents the natural, crustal component in atmospheric particles. We present the chemical and mineralogical composition of the desert dust of the three relevant synoptic systems and then, outline the differences between the mineraldominated compositions of desert dust and the nonnatural characteristics of the inorganic fraction of atmospheric particles during Persian Gulf trough conditions.

Crustal aerosols influence the atmospheric radiative balance through scattering and absorption processes (Fung et al., 2000; Arimoto, 2001; IPCC, 2007) and by acting as cloud condensation nuclei when sulfation and nitration occur (Levin et al., 1996). Dust outbreaks may also greatly increase the ambient air levels of PM recorded in air quality monitoring networks. This is especially relevant in southern Europe (Bergametti et al., 1989; Dayan et al., 1991; Alastuey et al., 2005; Rasheed et al., 2005; Escudero et al., 2005, 2007a; Gerasopoulos et al., 2006), Eastern Asia and in some Atlantic islands (Coude'-Gaussen et al., 1987; Chiapello et al., 1995; Arimoto et al., 1997). Dust particles frequently act as reaction surfaces for reactive gaseous species (Dentener et al., 1996; Alastuey et al., 2005)and the content of secondary PM may greatly increase when dust particles are present in the atmosphere. Moreover, atmospheric deposition fluxes of specific nutrients in southern Europe are also enhanced by dust outbreaks from Northern Africa (Ganor and Mamane, 1982; Camarero and Catala' n, 1993; Guerzoni and Chester, 1996; Avila and Roda, 2002). Oceanic or marine regions may be also highly influenced by crustal dust deposition, when dust iron and phosphate deposition may act as fertilizing agents for phytoplankton (Falkowski et al., 1998; George, et al., 2005; Arimoto, 2001). Furthermore, chemical compounds emitted from deserts may represent a source of alkalinity that neutralizes atmospheric acidity. Finally, dust transport episodes may also cause health impacts due to the high levels of PM and to the transport of anthropogenic pollution (Erel et al., 2006) and also to the possible transport of micro-organisms. On a global scale, most of the mineral dust is released to the atmosphere from arid or semiarid areas. The major dust source areas are located in subtropical latitudes of the North Hemisphereand extend from the West coast of North Africa, the Middle East, central and South Asia to China (Win, et al., 2010). The low precipitation in the Mediterranean basin favors the long residence time of PM in the atmosphere with the consequent impact on air quality. Furthermore, $>70 \%$ of the exceedances of the $\mathrm{PM}_{10}$ daily limit value (2008/50/CE European directive) in most Regional 
Background (RB) EMEP sites of Spain have been attributed to dust outbreaks (Escudero et al., 2007a). Similar findings are mentioned in Gerasopoulos et al. (2006) and for the Eastern Mediterranean Basin. According to Escudero et al. (2005), four meteorological scenarios originate the transport of African dusty air masses towards the Western Mediterranean Basin (WMB). These scenarios are characterized by the presence of (1) a North African High located at surface levels (NAH-S), (2) an Atlantic Depression (AD) situated in front of Portugal, (3) a North African Depression (NAD)and (4) a North African High located at upper levels (NAH-A). During spring and early summer, the development of Saharan thermal lows in the South of Atlas takes place under the influence of the strong thermal contrast between the temperature of the cold marine waters and the warm continental surfaces. These cyclones (NAD scenario) travel eastward along this thermal gradient and finally cross the Mediterranean between Libya and Egypt, constituting the main atmospheric scenario responsible for the transport of desert dust over the Eastern Mediterranean Basin (EMB), where also severe episodes can be associated with the combination of a deep trough over West Mediterranean and NW Africa and relatively high pressures to the Eastern part. Escudero et al. (2007b) developed and validated a methodology to determine quantitatively the daily African dust contribution to PM mass-levels recorded in Spain, based on statistical data treatment of PM data series recorded at $\mathrm{RB}$ sites. On the other hand, a number of studies on identifying and quantifying dust contributions to ambient PM levels in different parts of the Mediterranean basin are available (e.g., Gerasopoulos et al., 2006), but as far as we know there are no studies dealing with the entire Mediterranean basin as a whole. Furthermore, differences among local results may be also partially attributable to the different methodologies used. The aim of the present study is to quantify African dust contributions to mean $\mathrm{PM}_{10}$ levels recorded across the Mediterranean basin and to evidence spatial variations. To this end, a common methodology has been applied to PM datasets recorded at two aerosol research monitoring sites (MontsenySpain and Finokalia- Greece) and at a number of RB sites for a total 21 data series spread across the whole Mediterranean Basin.

\section{METERIALS AND METHODS}

The measurement period and type of air quality monitoring sites from which PM data series have been used in the present study. These are:
- Aerosol research monitoring sites: Helwan region represent desert weather

- Analysis the samples

- Regional air quality monitoring networks, available from Airbase-EEA. In order to characterize the daily atmospheric scenarios with incidence on PM levels, a number of tools were used

- NCEP meteorological maps and daily backtrajectories calculated by HYSPLIT4 model (Draxler and Rolph, 2003). Daily 5-days backtrajectories were calculated at $12 \mathrm{~h}$ GMT at receptor points of 700, 1500 and 2500 m.a.s.1, by modeling the vertical velocity

The occurrence of African dust outbreaks was detected with the previous tools, coupled with the information from the aerosol maps: Marine Meteorology Division of the Naval research Laboratory, USA (NRL) (http://www.nrlmry.navy.mil/aerosol); $\quad$ SKIRON aerosol concentration maps (http://forecast.uoa.gr); BSC-/DREAM dust maps (http://www.bsc.es/projects/earthscience/DREAM/); and satellite imagery provided by NASA Sea WIFS project (http://seawifs.gsfc.nasa.gov/SEAWIFS.html).

Once the PM mass data were obtained, the days under the influence of African dust outbreaks (which will be referred to as NAF) for each receptor site were evidenced with the above methodology. Subsequently, a method based on the statistical data treatment of time series of $\mathrm{PM}_{10}$ levels (Escudero et al., 2007b) was used for the quantification of the daily African $\mathrm{PM}_{10}$ load during dust outbreaks at each site. The daily RB levels can be obtained by applying a monthly moving 30th percentile to the $\mathrm{PM}_{10}$ time series at a RB station after a prior extraction of the days with NAF influence. Then, for a given day under NAF influence, the net dust can be obtained by subtracting the calculated RB value from $30^{\text {th }}$ percentile to the measured $\mathrm{PM}_{10}$ concentration. The exclusion of the NAF days for the calculation of the RB levels and the subsequent estimation of the net dust load may yield an overestimation of the dust load. However, this methodology was validated at three RB sites by comparing the estimated net dust with the experimental crustal load determined in $\mathrm{PM}_{10}$ samples (Escudero et al., 2007b). The correlation $\left(\mathrm{R}^{2}>0.86\right)$ and the equivalence were significant in the three cases. A statistical analysis was performed on the $\mathrm{PM}_{10}$ data collected in the selected stations and mean, standard deviation, relative standard deviation and skewness of the data distributions were derived. Based on a number of samples ranging from about 600 to more than 4000 depending on the station, this kind of statistical analysis allowed for the determination of the mean behavior of 
$\mathrm{PM}_{10}$ levels and African dust contributions across the Mediterranean basin. A selection of samples of PM from Spain, Cyprus and Crete, collected during NAF episodes, was also studied under the Scanning Electron Microscope (1450 SEM, JEOL5900LV). Analyses were performed manually on carbon-coated samples using an Energy Dispersive X-ray microanalysis system (EDX) with a spectrum acquisition time of $30 \mathrm{~s}$ live time. Microscope working distance was $10 \mathrm{~mm}$, accelerating voltage $20 \mathrm{kV}$ and beam current $1 \mathrm{~mA}$.

Measurement data: particulate matter is a complex mixture of particles of different sizes, different sources and different chemical and physical properties. Various methods have been described to determine different indicators of particulate matter in ambient air. In principle, sampling and analysis can be distinguished. During sampling, selected parts of the SPM are usually collected, often on filter material. Sampling can be followed by mass determination, or by chemical analysis. Sampling is often used to differentiate particles according to their size. Fig. 1 (USEPA, 1996) shows an idealized size distribution of particulate matter in ambient air and measurement techniques to cover specific fractions. Sampling and analysis can lead to artifacts. Because of the difficulties in measuring particles larger than $10 \mu \mathrm{m}$ and because these larger Which exclude larger particles. particles are not regarded as relevant in connection with health issues, it is generally recommended to use inlets. The measurements are then referred to as $\mathrm{PM}_{10}$ and expressed in $\mu \mathrm{g} \mathrm{m}^{-3}$.

Based on the results of the studies summarized in Table 1, it was assumed that the risk of premature death increase, (dRR), is ca. $2 \%$ per $10 \mu \mathrm{g} \mathrm{m}^{-3}$ of $\mathrm{PM}_{10}$ (range $1-4 \%$ per $10 \mu \mathrm{g} \mathrm{m}^{-3}$ ). This value is smaller than estimated by the American studies to adjust for the possible difference between the risk of death in a cohort observed longitudinally in the period of several years (being a base for the studies) than in a cross-sectionally observed population. It was also assumed that the exposure-response association is the same for the secondary and primary particles and that the effects are additive. Furthermore, we will assume that the total population (all ages) is susceptible to the pollution and that the mortality due to all natural causes (and not the accidents) may be increased by the pollution. Therefore, it is assumed that the baseline mortality rate is 900 per 100000 people (i.e., $0.9 \%$ ) annually, which is close to the average crude mortality rate (all causes except accidents) in Europe. Those estimated numbers of deaths attributable to long-range transboundary air pollution in all European population are similar to the number of deaths attributed to the PM pollution in excess of $10 \mu \mathrm{g} \mathrm{m}^{-3}$ in the European cities (as shown in Table 1).

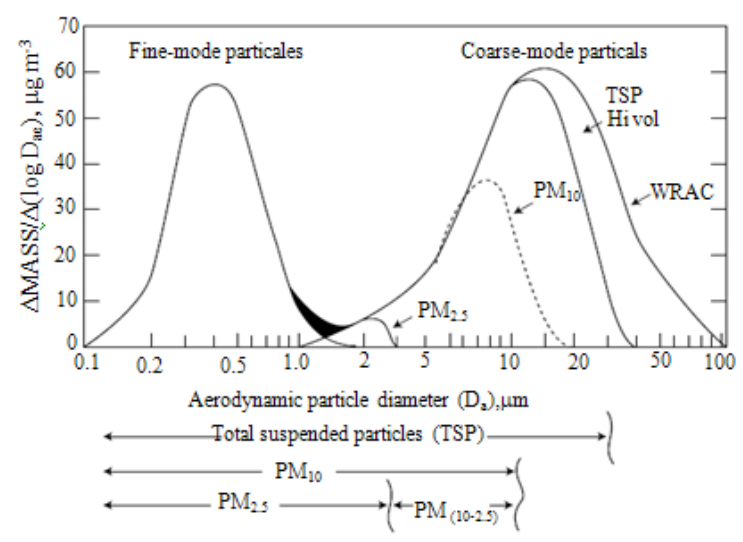

Fig. 1: Schematic representation of the size distribution of particulate matter in ambient air (USEPA 1996)

Table 1: Average concentration values determined within selected ranges of temperature

\begin{tabular}{|c|c|c|c|c|c|}
\hline $\mathrm{PM}_{10}$ & $\mathrm{CO}$ & $\mathrm{SO}_{2}$ & $\mathrm{NO}_{2}$ & $\mathrm{O}_{3}$ & \\
\hline $\mathrm{T}=10-15^{\circ} \mathrm{C}$ & 197 & 8 & 12 & 56 & 16 \\
\hline $\mathrm{T}=16-20^{\circ} \mathrm{C}$ & 237 & 6 & 20 & 67 & 28 \\
\hline $\mathrm{T}=21-30^{\circ} \mathrm{C}$ & 154 & 5 & 33 & 80 & 61 \\
\hline$>30^{\circ} \mathrm{C}$ & 110 & 5 & 58 & 107 & 85 \\
\hline
\end{tabular}

Measurements, which do not exclude the larger particles, are referred to as TSP. Because small particles are believed to be even more relevant in connection with health, there is also a move towards using sizeselective inlets, which exclude particles larger than 2.5 $\mu \mathrm{m} \quad\left(\mathrm{PM}_{2.5}\right)$. Cascade impactors, which separate particles in size classes according to their aerodynamic diameter, are also used. In general, the difference between the mass concentration of TSP and $\mathrm{PM}_{10}$ and between $\mathrm{PM}_{10}$ and $\mathrm{PM}_{2.5}$ is larger in urban and industrial areas than in rural areas. This is because in rural areas, a larger fraction of the suspended particle mass is from secondary pollutant particles, which are formed as a result of chemical transformation involving gaseous precursors. Large particles are also subject to more rapid sedimentation and deposition, which also leads to a higher proportion of $\mathrm{PM}_{2.5}$ relative to TSP and $\mathrm{PM}_{10}$ in areas at some distance from the emission sources. Re-suspension of large particles (dust) may, however, decrease the proportion of a $\mathrm{PM}_{10}$ in TSP in rural areas, e.g. in the dry periods, with $\mathrm{PM}_{10}$ contributing not more than $65 \%$ of TSP. 20 .

\section{RESULTS AND DISCUSSION}

African dust single particle composition: When examining the sources of $\mathrm{PM}_{10}$ particulates, it is 
possible to make a distinction between what are referred to as primary particles and secondary particles. Primary particles are those emitted directly into the atmosphere from sources such as road traffic, coal burning, industry, windblown soil and sea spray. Secondary particles are those formed within the atmosphere by the chemical reaction of pollutant condensation of gases, as in the case of sulfate and nitrate salts which are the result of the oxidation products of sulfur dioxides and nitrogen oxides respectively. As mentioned above, primary particles can have different sources. These can be natural (winds blowing up small particles of soil, dust released by explosions of volcanoes) or result from human activities. (-0.44) and $\mathrm{NO}_{2}(-0.16)$. Since the variations of $\mathrm{NO}_{2}$ over Cairo city and its surrounding suburbs are small (between 60 and $80 \mu \mathrm{g} \mathrm{m}^{-3}$ ), their impact on UV radiation is expected to be very weak. 6 . A reduction of $39.6 \%$ was reported during the days with air pollutants in the range of $250 \leq \mathrm{PM}_{10} \leq 350 \mu \mathrm{g} \mathrm{m}^{-3}$. There are different sources for SPM and $\mathrm{PM}_{10}$ and they can vary greatly depending on the location (Burton et al., 1996).

Suspensions of dust originating from soil and also evaporation of sea water are considered as large sources of particles worldwide. Suspension of soil dusts are caused by the action of the wind on dry loose soil. The amount of this dust in the Northern Hemisphere is estimated to be about 150 million tons per year; if the Sahara Desert were included in the calculation, this amount would double. The particles are generally coarse and may settle, but they can be re-suspended in the air by such agents as the wind, dry weather or moving traffic (Quality of Urban Air Review Group, 1996). The size distribution and chemistry of the airborne dust of cities in the UK show that this source contributes significantly to SPM pollution. For coastal areas, the contribution of salt particles to the SPM figure is very important. These salt particles result from the evaporation of minute droplets sent into the atmosphere by breaking waves. Other inorganic particles suspended in seawater also become airborne in this manner, while sea salt particles often have been measured in inland locations.

In view of the results given in Fig. 2 which shows the daily values of $\mathrm{PM}_{10}$ and $\mathrm{CO}$ measured at Cairo during 2003, it is noticed that the mean values of the relative attenuation in autumn $(28.8 \%)$ and spring $(27.6 \%)$ are rather high and closer to summer value $(25.5 \%)$ than to winter value $(22.6 \%)$. The higher values in autumn and spring may be attributed to $\mathrm{PM}_{10}$ and $\mathrm{CO}$ effects. This added to the effect of Khamasin storm, which carries large amounts of sand/ dust from the nearby desert. Such particles are frequently found in the lowest part of the troposphere (i.e. the boundary layer). To be more precise a reduction of $39.6 \%$ was reported during the days with $\mathrm{PM}_{10}$ in the range of $250 \leq \mathrm{PM}_{10} \leq 350 \mu \mathrm{g} / \mathrm{m}^{3}$. This reduction describes the effect of $\mathrm{PM}_{10}$ on the UV radiation reaching the ground, being free from cloud and column ozone, but it includes the influence of other trace gases and scattering processes (i.e. $8 \leq \mathrm{CO} \leq 12 \mathrm{mg} / \mathrm{m}^{3}, 60 \leq \mathrm{SO}_{2}<100 \mu \mathrm{g} / \mathrm{m}^{3}$ and $\left.65 \leq \mathrm{NO}_{2} \leq 80 \mu \mathrm{g} / \mathrm{m}^{3}\right)$.

Samples from west and east Mediterranean were studied under the SEM in order to compare the chemical composition of individual particles during the intrusion of air masses from North Africa. Following the approach and methodology explained in Moreno et al. (2003) where SEM limitations are discussed one can compare the relative importance of mineralogical groupings between samples, based on elemental ratio values, differentiating between felsic silicates ( $\mathrm{Si}$ - and Al-rich, such as quartz, feldspars, white micas or clays) from more mafic silicates (rich in $\mathrm{Fe}$ and $\mathrm{Mg}$, as serpentine, talc, vermiculite or amphiboles). The samples selected were $\mathrm{PM}_{10}$ and $\mathrm{PM}_{2.5}$ filters from Cyprus (Larnaka, Pafos, Strovolos), Crete (Finokalia) and NE Spain (Montseny).

A total of 600 particles $\left(\mathrm{PM}_{10}\right.$ and $\left.\mathrm{PM}_{2.5}\right)$ were identified from samples collected at each of the 3 sites in Cyprus (November 2008), with no significant differences between the overall major element chemistry of particle populations analyzed at the 3 sites. Silicates are dominant $\left(50-55 \%\right.$ of $\mathrm{PM}_{10}, 70-75 \%$ of $\mathrm{PM}_{2.5}$ ), followed by carbonates (33-40\% $\mathrm{PM}_{10} ; 15-22 \%$ $\mathrm{PM}_{2.5}$ ), sulphates (up to $13 \%$ ) and sea salt (up to $8 \%$ ).

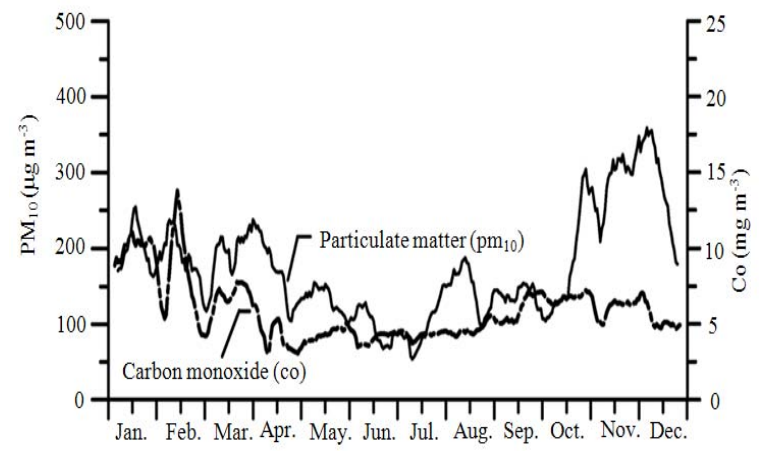

Fig. 2: Daily values of $\mathrm{PM}_{10}$ and $\mathrm{CO}$ measured at Cairo during 2003 


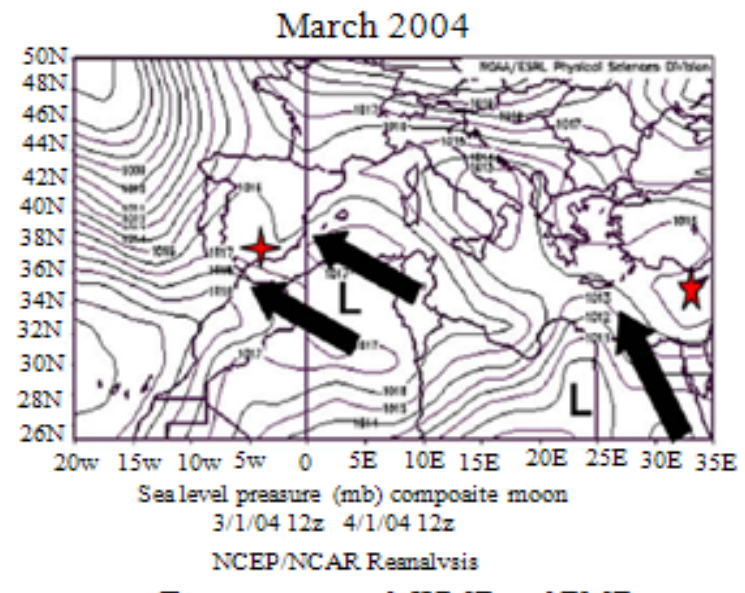

Transport towards WMB and EMB

(a)

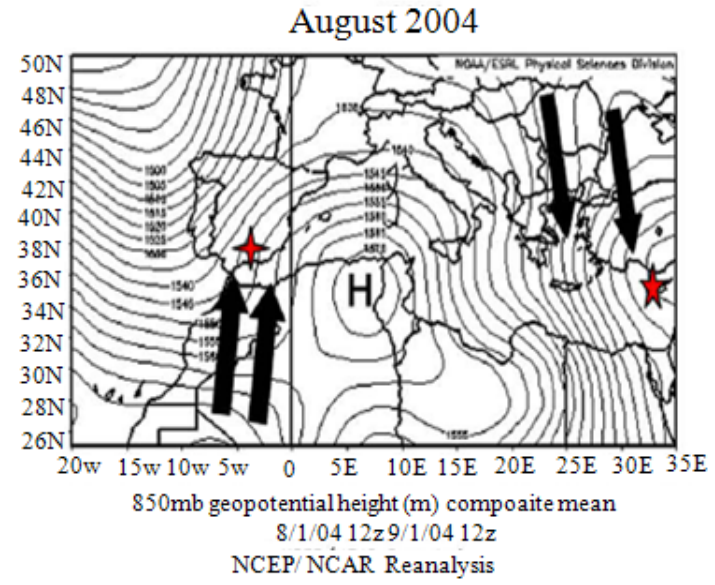

Transvort toward WMB bur not to EMB

(b)

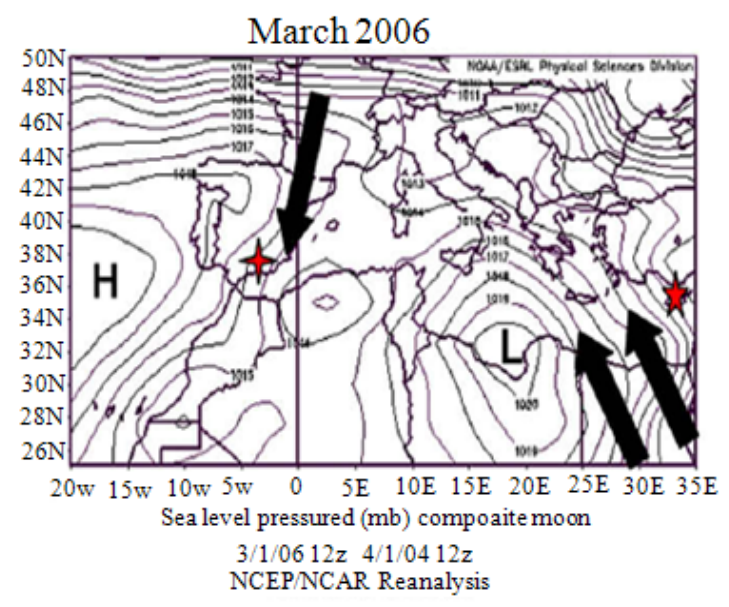

Transport towards EMB but not to WMB

(c) 


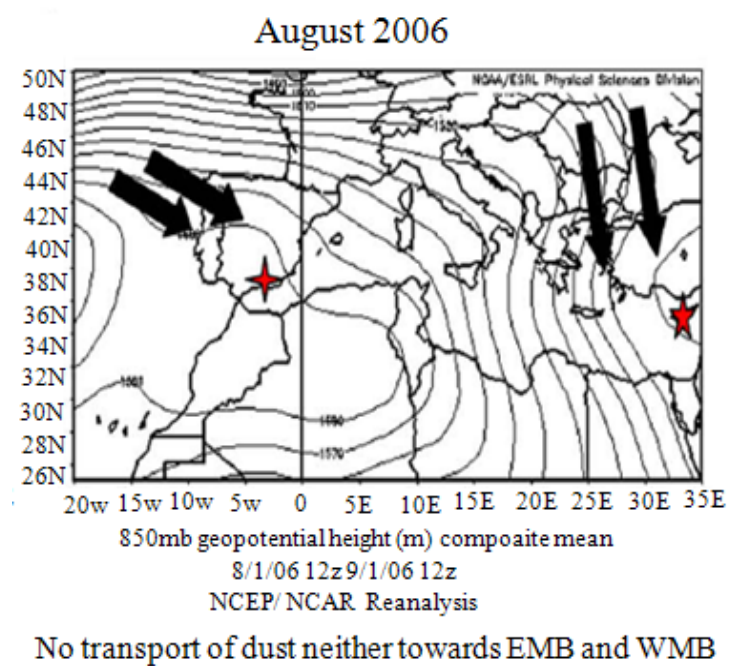

(d)

Fig. 3: Examples of some meteorological scenarios favouring or preventing the transport of African dusty air masses towards the WMB and the EMB. The four-peak star locates V1'znar (Spain) and the five-peak star situates Ayia Marina (Cyprus)

With regard to silicate composition, Al-rich clay minerals such as kaolinite and illite are very common in the $\mathrm{PM}_{10}$ silicates, whereas, siliceous compositions likely to represent quartz or biological silica (e.g., diatoms) are more abundant in $\mathrm{PM}_{2.5}$. Compositions in between these two groups, representing feldspathic compositions, Si-rich clays and mixed analyses, form $35-46 \%$ of all silicates with no marked difference between coarse and fine samples.

A total of 800 particles from the Crete $\mathrm{PM}_{10}$ samples (April and November-December 2008) were similarly identified. Most of these particles are felsic silicates (clay minerals, silica and feldspar: 74\%), with lesser amounts of carbonates (up to 15\%), sulphates (up to $11 \%$ ) and mafic silicates (4\%). Al-rich clays compositions (such as kaolinite and illite) are clearly dominant over Si felsic and silica compositions (Fig. 3b). We can conclude overall that the Cyprus $\mathrm{PM}_{10}$ samples are more siliceous and less Al-clay rich than those collected from Crete. Sea salt was detected as a common component but only in some of the samples (up to $9 \%$ ). There are no obvious differences between those samples collected during spring (April) and winter (Nov-Dec) dust intrusions.

A total of 600 individual mineral particle analyses were obtained from NE Spain (Montseny) samples collected during NAF episodes from Central Africa (July 2004) and NW Africa (February 2004). The PM10 fraction of these samples is dominated by silicate PM10 (92-97\% in number), with low proportions of Ca- (and Mg-) carbonates (1-4\%), sulphates (1\%) and carbonaceous compounds (1-3\%) (Fig. 3a). These proportions are different in the PM2.5 fraction which has much fewer silicate particles (up to 67\%) and many more carbonaceous PM (up to 26\%), whereas sulphate content is similar between the two PM fractions. Aluminous felsic silicates, presumably mostly kaolinitic and illitic-smectitic clays (Moreno et al., 2006) are more common in the samples sourced from Central Africa than that from NW Africa. Thus, SEM results show Cyprus as the most calcareous airborne samples (presumably they are richest in calcite), with silicates being more common in the $\mathrm{PM}_{2.5}$ fraction and carbonate in the coarser fraction $\left(\mathrm{PM}_{10}\right)$ and with no significant compositional differences between the 3 collecting sites during the same intrusion episode. Crete samples on the other hand are the richest in Al-clays (e.g., kaolinite and illite) and show no obvious differences between samples collected during NAF events occurred in different times of the year (April and NovemberDecember). The latter observation is perhaps not surprising as the back-trajectories for the different episodes only indicate slight differences in the source areas. Finally the samples from Montseny (NE Spain) are the least calcareous $(<5 \%$ carbonate) and in this sense are chemically more similar to the Crete samples rather than the Cyprus samples. With regard to silicate composition, the closest similarities are between the airborne samples collected on Crete and those arriving in NE Spain from Central North Africa as shown in Fig. 3. 
Mineralogical analysis: The mineral or crystalline components of airborne particles can be determined by the use of X-Ray powder Diffraction (XRD). This technique identifies compounds based on their crystalline structures. The large amount of material needed for analysis is a major inconvenience. A minimum of $5 \mathrm{mg}$ of material is usually required to produce reliable XRD results. Unfortunately, this amount of airborne material is not easily obtained during a sampling procedure. Single particle electron diffraction can also be used for identification when a transmission electron microscope is employed. The finer $\mathrm{PM}_{10}$ particles are mainly formed by:

- Secondary particles such as sulfates, nitrates and chloride salts of ammonium, products of the reaction of $\mathrm{SO}_{2}, \mathrm{NO}_{2}$, hydrochloric acid and ammonium ions in atmospheric conditions

- Heavy metals originating from anthropogenic sources, such as smelting plants )iron, cadmium, zinc) and combustion processes (in urban locations, combustion of leaded fuel releases lead)

- Elemental carbon, which is a product of incomplete combustion processes, including the combustion of fuels (for the transport sector), coal, biomaterial. The surface area of elemental carbon particles is considerably increased by their porous surface; hence their ability to receive more airborne chemical substances (such as organic compounds) is greatly enhanced

- Organic compounds that condense at the surface of tiny nuclei are adsorbed on carbon material, the small particles of which present a larger surface area for the condensation and/or adsorption of chemical species. Studies indicate that organic mutagenic compounds are mainly associated with the 0-2.5 m particles (Watts et al., 1988)

The coarse fraction of PMm0 is formed mainly by minerals and natural salts coming from dust created by wind or marine aerosols. Some anthropogenic species also have been found in the coarse fraction, but in much smaller proportion when compared with the finer fraction. This is the case with carbon black, halogen (as bromine and iodine (sulfur, vanadium, nickel, zinc, indium and lead. These were recorded in average ratios) fine/coarse) of over 2 and up to 7 for carbon black and iodine (Maenhaut et al., 1996).

Fig. 4 can be summarized as follows: Silicon, $\mathrm{Si}$ and calcium, $\mathrm{Ca}$, are regarded as crustal element. They are important components of $\mathrm{PM}_{10}$ measured in Cairo. The two elements hold about $23 \%$ of $\mathrm{PM}_{10}$ mass. The presence of coarse silicon can be ascribed to erosion from desert land surrounding monitoring station.

Ongoing building activities and degradation of building elements can be considered as additional sources for increasing silicon level.

The same effect appears in soil-derived elements, $\mathrm{Ca}$ and titanium, Ti. Calcium, $\mathrm{Ca}$, concentrations are much similar in all locations except for increased coarse Fraction in Helwan site which are to be ascribed to partly degradation of buildings, partly to emanating from industries such as cement plants. Sulfur, $\mathrm{S}$, concentration indicate the determining contribution of long-range transport processes during which gaseous sulfur emission is subject to a continuous conversion to particulate secondary sulfur. The increased values in sulfur, $\mathrm{S}$, concentration can be considered as an indication for possible influence of Shoubra El- Kheima on Cairo air. Potassium was ascribed to mixed natural (e.g., soil derived contribution as in the silicon case) and anthropogenic sources. Low chlorine, $\mathrm{Cl}$ and sodium $\mathrm{Na}$ concentrations can be understood as a strong sea-derived contribution. No attempt has been made to use seawater related enrichment factors to search for a sea-spray contribution to the local chlorine in Cairo city. Small concentration elements of aluminum Al, zinc, $\mathrm{Zn}$, manganese, $\mathrm{Mg}$ and iron, $\mathrm{Fe}$ indicating the importance of soil derived dust of traffic origin. Finally, the composition of dust deposited in Cairo city during Khamasin storm was similar to that deposited during normal weather conditions, indicating that the composition of dust deposited during the storm over a wide area of the desert around Cairo was uniform.

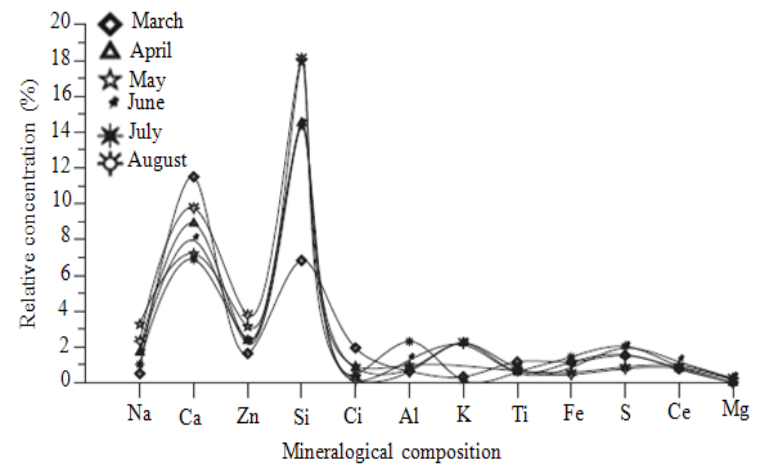

Fig. 4: X-ray diffraction analysis of dust collected from all traps in the city of Cairo 
The composition of particulate material in urban air samples can be divided into particulate elemental carbon or carbon black (which comes from road traffic and is associated with organic compounds in smoke particles) and water-soluble or insoluble inorganic compounds. The elemental carbon particles result from the incomplete combustion of fuels and lubricating oils and are generally small, forming part of the finer fraction of $\mathrm{PM}_{10}$ matter. They have a porous surface that increases the area available for adsorption processes.

Organic compounds, heavy metals and soluble inorganic material can be carried by elemental carbon particles. Health concerns were originally focused on this fact, but it is now recognized that elemental carbon can be dangerous by itself. In the UK, diesel combustion is believed to be responsible for $80-95 \%$ of Particulate Elemental Carbon (PEC). Measures made in Birmingham (Harrison et al., 1996) indicated a concentration of $3 \mu \mathrm{g} \mathrm{m}^{-3}$ PEC which was $10 \%$ of the total $\mathrm{PM}_{10}$ mass. Soluble inorganic compounds can be divided into several categories.

Aerosol acids: Acidity can result from partial neutralization of the airborne acid species present in the atmosphere (nitric acid, sulfur acid, bisulfates) owing to an insufficient quantity of basic species, i.e., ammonium ions. These basic species are Insoluble inorganic material is typically associated with the coarse fraction of PM10 matter and is formed by soilderived particles It includes compounds such as o quartz $\left(\mathrm{SiO}_{2}\right)$, calcite $\left(\mathrm{CaCO}_{3}\right)$, epsomite $\left(\mathrm{MgSO}_{4} .7 \mathrm{H}_{2} \mathrm{O}\right)$, gypsum $\left(\mathrm{CaSO}_{4} \cdot 2 \mathrm{H}_{2} 0\right)$, chlorite, kaolinite and montmorillonite. In the UK this fraction can represent nearly $25 \%$ of the total PMl0 mass. Metals can be found in a variety of different compounds. They exist in both a soluble and insoluble elemental state. They may also be combined as organometallic compounds. Analysis of heavy metals in airborne samples tends to be difficult because of their low concentrations. Nevertheless, they can be detected. Their characterization and quantification are of special interest because of the health issues they raise

The chemistry of $\mathrm{PM}_{10}$ varies with the location and source. Most global studies have focused on the gravimetric evaluation of the amount of $\mathrm{PM}_{10}$ matter and certain substances carried by it, but few studies have attempted to achieve a complete characterization of the physical and chemical characteristics of this material. Most surveys and sampling campaigns have covered the analysis of trace metals and organic pollutants associated with $\mathrm{PM}_{10}$ particles (Quality of Urban Air Review Group, 1996). These substances constitute only a small percentage of the total mass of
PMi0 matter. This also is the case in the UK, where studies have been performed at different locations and times using a range of techniques (Hutchison, 1996). $\mathrm{PM}_{10}$ matter does not have a constant composition, thus studies give us only a general idea of the composition of $\mathrm{PM}_{10}$ matter in the UK. A typical breakdown of $\mathrm{PM}_{10}$ particulate matter in the UK has been provided by the Department of the Environment (Quality of Urban Air Review Group, 1996). This analysis reveals that some material can consist of ammonium 5\%, sulfate, nitrate and chloride $30 \%$, carbonaceous material $40 \%$, metals $5 \%$ and insoluble material (minerals) $20 \%$. This analysis was performed on the data from several studies since no survey covering all the components simultaneously has yet been undertaken in the UK (Quality of Urban Air Review Group, 1996). One chemical analysis of airborne $\mathrm{PM}_{10}$ at Cardiffyielded the following result: Soluble inorganic matter $40.8 \%$, insoluble inorganic matter $19.2 \%$, organic matter $40 \%$ (Hutchison, 1996). As described previously, the chemistry of ambient airborne particulate material is complex. The chemistry is also affected by physical characteristics of the particles, e.g., their size distribution. Complete characterization of a $\mathrm{PM}_{10}$ fraction is therefore a difficult process owing to both its material complexity and also to the fact that only very small samples of airborne particulates can be collected conveniently. Available analytical methods have not dealt with these inconveniences, since little attention has been given to the total identification of airborne particulate material. In general, $\mathrm{PM}_{10}$ samples can be described most conveniently as a number of individual fractions, each of which is either soluble or insoluble in water or in organic solvent; the insoluble component is either carbon-based or inorganic material. This fractionation enables us to make some approximate division of the sample by source. For specific geographical locations, the contribution of any local industrial activity to the airborne particulate sample composition can be assessed and distinguished from the natural contributions of the sea and from secondary particulate formation due to atmospheric chemistry activity.

Epidemiologic evidence on outdoor air pollution and lung cancer: Nearly five decades have passed since investigators in the UK initiated studies to test whether outdoor air pollution increases lung cancer risk. Three lines of epidemiological evidence have been relevant:

- Studies of lung cancer risk in migrants to areas having differing lung cancer risk from the native country 
- Ecological studies comparing lung cancer rates in areas assumed to have differing air pollution exposures and

- Case-control and cohort studies that have estimated lung cancer risk associated with exposures of individuals

Studies of migrants, reviewed in detail elsewhere have provided support for the general hypothesis that air pollution is associated with lung cancer risk. Migrants from countries with higher lung cancer rates to countries with lower lung cancer rates tend to develop lung cancer at rates higher than those of the new country of residence. Ecological studies (i.e., studies involving the population as the unit of analysis) have also supplied support evidence by comparing rates for urban and rural populations and for populations estimated to have higher and lower exposures to urban air pollution.

Case-control and cohort studies have the advantage of offering information on potential confounding and modifying factors, such as cigarette smoking. However, a strategy is needed for estimating air pollution exposure using historical information. Approaches have been based around reported residence locations and use of various surrogates. Misclassification of exposure is an evident limitation of such studies and would tend to reduce risk estimates and statistical power.

Exposure biomarkers-that is, indicators of exposure or dose measured in biological material - offer a new approach to quantifying the lung cancer risk associated with air pollution. Potential biomarkers for lung cancer risk include actual levels of the putative carcinogen in biological materials, adducts of potential carcinogens or metabolites down to DNA and antibodies against such adducts. Biomarkers of exposure to respiratory carcinogens provide an intermediate outcome for investigation that may prove valid surrogates for risk. Levels of adducts, for example, may prove to be a predictor of risk and may serve to bridge from animal models and in vitro assays to human risk.

Costing the health effects of poor air quality: If people's preferences are a valid basis upon which to make judgments concerning changes in human 'wellbeing', then it follows that changes in the risk of mortality should be valued according to what individuals are willing to pay (or, depending on the context, willing to accept as compensation) to forego the change in the risks that they face. The proper valuation of health impacts in monetary terms is necessary in order to allocate resources in an efficient manner between projects aimed at health and safety and other possible items of expenditure. This practice has long been followed in the planning of transportation systems in so far as the prevention of accidents is concerned. Recent attention has turned to the health effects of air pollution with the publication of empirical studies identifying current ambient levels of air pollution as a significant cause of excess mortality. Those same estimates used to value accidental deaths have been used to value lives which, it is predicted, have been lost as a result of poor quality. The purpose of attaching values to these ill-effects is motivated by much the same set of concerns that prompt transport planners, namely a desire to allocate resources between air pollution abatement measures, investment in public transport systems and private consumption (particularly consumption of private transport). Putting a monetary value on the costs and benefits of air pollution control strategies provides a metric of human preferences with which the desirability of a range of options can be assessed. Merely enumerating the physical effects of air pollution control strategies is not on its own sufficient to assess their desirability. And yet for a number of reasons the valuation of the health effects of air pollution remains a contentious subject, even among those who accept the necessity of such valuation exercises in the case of designing transport systems.

Population exposure and estimation of health impacts: This chapter addresses the contribution of the secondary sulphate, nitrate and ammonium particulate matterand of the primary particulate emissions to human exposure. This is based on the relationship between particulate concentrations, spatial distribution of population and health risks derived from epidemiological studies as described in the previous chapters. Due to the focus of this report on the LRTAP, the calculations are based on estimates of background concentrations of particulates and do not include the local contributions of emissions within the grid square in which they originate. Total exposure to particulate matter, especially in urban areas, may be considerably higher.

The maps of concentration in units of $\mu \mathrm{g} \mathrm{m}^{-3}$ above may be combined with population data mapped on to the EMEP grid, to derive estimates of the overall exposure. The estimated population density is based on the information on the number of residents in subnational regions and in cities of Europe in the beginning of the 1990s. The total number of people covered by the EMEP grid is estimated to be 760 million. The resulting exposure is expressed in person grams per cubic meter (person* $\mathrm{g} \mathrm{m}^{-3}$ ). 
Recent attention has focused on the gravimetric measurement of the $\mathrm{PM}_{10}$ fraction of airborne particulate matter, because of the possible health impact that has been suggested by several recent studies (Pope, 1989; Royal Commission Report, 1994). The term $\mathrm{PM}_{10}$ stands for a fraction of airborne matter that contains particles with an aerodynamic diameter (which implies a specific gravity equal to one) of less than 10 gtm. Technically speaking, the $\mathrm{PM}_{10}$ fraction of an airborne dust consists of particles that pass through a size-selective inlet with a $50 \%$ efficiency cut-off at 10 gtm aerodynamic diameter (Warren Spring Laboratory, 1994). An interest in the fraction called $\mathrm{PM}_{2.5}$ (which definition is analogous to $\mathrm{PM}_{10}$ ) has also been given special consideration, since this fine fraction is suspected to be the major contributor to health effects because it can penetrate easily to the innermost regions of the lungs. Assessment of health impact of air pollution is based on the estimated exposure data and information on exposure-response relationship derived from the epidemiological studies. Several assumptions must be made in deriving such estimates for the possible impact of long-range transboundary air pollution. An important one is the assumption that the possible differences between the chemical and physical characteristics of the particles from the long range transport and those predominant in the urban areas, where most of the epidemiological studies were performed, have no significant effect on the exposureresponse associations. Another one is about the continuity and linearity of the association throughout the exposure range, including the lowest concentrations of the particles estimated. The most relevant health effects to be considered in respect of the long-range transboundary air pollution are the effects of long-term exposures observed in cohort studies. Estimation of the effects of short-term changes in the pollution levels is not possible at present, due to the lack of estimates of diurnal variability of concentration of particulate matter from long-range transport of pollution. The estimates are also consistent with the estimates derived by the trilateral research team of Austria, France and Switzerland for the study on health impacts of air pollution from road transport. Assuming the linearity of the exposureresponse association, the estimated impact, i.e., the number of premature deaths, is proportional to the extent of the exposure. Therefore the exposure maps can represent the spatial differentiation of impact in Europe. According to the definition of exposure used, its level in each grid square is heavily influenced by population density and not only by the estimated concentration of the pollution. Therefore the highest estimated number of cases per grid square attributed to the pollution from long-range transport is expected in the relatively densely populated areas stretching from southern Poland to southern England and in the area in Russia near Moscow. The ratio of the expected impact in the grid cells in an upper quartile of impact distribution (red and orange cells) to the impact in the lowest quartile was 12-15 for primary and secondary $\mathrm{PM}_{10}$ in 1990. For secondary particulates in 1996, the ratio was 1.5; however this was due to a rather high value of the 25 th percentile, with the median exposure levels lower in 1996 than in 1990. The ratio between the upper and lower quintiles (i.e., the values cuttingoff the highest and lowest $5 \%$ of exposure to secondary $\mathrm{PM}_{10}$ distribution; red to blue cells) was ca. 700 for both 1990 and 1996. Another consequence of the assumption of linearity of exposure-response relationship is that the reduction of the exposure related to the implementation of the convention will reduce the health effects proportionally. This will be done the most effectively by the reduction of the particle concentration in densely populated parts of Europe. Between 1990 and 1996, the value of the 75th percentile of exposure (and effects) decreased by $22 \%$ and the areas with relatively high risk in 1996 were shifted more to the south of Europe since1990.

\section{CONCLUSION}

Regional background $\mathrm{PM}_{10}$ levels across the Mediterranean show clear increasing trends from north to south and west to east of the Basin. These trends are almost coincident with the $\mathrm{PM}_{10}$ African dust load. Independently, when subtracting the PM load attributed to the African dust, the background levels are 5-10 $\mathrm{mgm}^{-3}$ higher in the EMB when compared with those in the WMB, mainly due to the higher background contributions of anthropogenic compounds (sulphate and organics) and sea spray.

Marked $\mathrm{PM}_{10}$ seasonal trends are evidenced, largely driven by the occurrence of African dust events. Thus, the higher frequency of dust events in spring-early summer over the EMB causes higher PM levels. Likewise, the summer maximum observed in the WMB roughly coincides with the most intense period of African dust outbreaks, but in this region also with the development of recirculation's of aged air masses. Furthermore, a marked seasonal trend is still evident when subtracting the African dust load. This is characterized by a high RB summer maximum (driven by low precipitation, high insulation) and a winter minimum.

There remains a persistent basis for concern that indoor air pollution may cause lung cancer in both 
smokers and non-smokers. Carcinogens can be measured in indoor and outdoor environments and toxicologic data indicate the potential for human carcinogenicity. Epidemiologic research shows evidence of effects of indoor and outdoor air pollution on lung cancer risk, albeit weak for some agents. On the other hand, levels of exposure to many agents would not be expected to greatly increase risk and the multifactorial etiology of lung cancer lowers the signalto-noise ratio. Research is still needed on air pollution and lung cancer to guide policies for protection of public health. Direct epidemiologic observation of exposed populations can provide the best information for evaluating the magnitude of outdoor air pollutionrelated excess lung cancer, In general, large-scale epidemiologic studies of air pollution and lung cancer are needed if we are to obtain sufficiently informative data. Large numbers of cases will be necessary to measure the effects of air pollution among women and ethnic minorities and to measure the joint effects of air pollution and other factors, such as occupation and smoking. Without improved epidemiologic methods, however, even large studies may fail to in fbrm. Current development of biologic markers of exposure to and molecular effects of, PAHs represents one approach to improving epidemiologic methods. Markers of genetic susceptibility are also needed. In addition and of equal importance, methods for the retrospective estimation of lifetime exposure to air pollutants should be developed and tested, so that large case-control and retrospective cohort studies can be feasibly conducted. These methods could combine time-activity information with data from national aerometric databases, such as those maintained by the US Environmental Protection Agency. This effort should include development of methods to characterize, quantify and adjust for exposure measurement error. For lung cancer, urban and relatively unpolluted areas with established population-based tumor registries might be targeted. The air pollution mixtures in various US population centers should be characterized both in terms of physical and chemical constituents and of sources of major constituents. If possible, retrospective characterization of levels of certain constituents could be accomplished. This information would aid greatly in the interpretation of between-city patterns of lung cancer occurrence. New designs and statistical methods for air pollution studies may provide additional insights. Navidi and Thomas (1993) and Prentice and Sheppard (1995) have described hybrid studies which combine ecologic-level contrasts of air pollution effects between cities with individual-level data on covariates, combining the strengths of both ecologic and individual-level studies. Studies using these designs could contrast the effect on lung cancer of exposure to the pollutant mixtures of different cities while effectively controlling confounding by cigarette smoking, diet or other factors and adjusting for exposure measurement error.

\section{REFERENCES}

Alastuey, A., X. Querol, S. Castillo, M. Escudero and A. Avila et al., 2005. Characterisation of TSP and $\mathrm{PM}_{2.5}$ at Izaña and Sta. Cruz de Tenerife (Canary Islands, Spain) during a Saharan dust episode. Atmos. Environ., 39: 4715-4728.

Arimoto, R., 2001. Eolian dust and climate: Relationships to sources, tropospheric chemistry, transport and deposition. Earth-Sci. Rev., 54: 29-42. DOI: 10.1016/S0012-8252(01)00040-X

Arimoto, R., B.J. Ray, N.F. Lewis, U. Tomza and R.A. Duce, 1997. Mass-particle size distributions of atmospheric dust and the dry deposition of dust to the remote ocean. J. Geophys. Res., 102: 1586715874.

http://europa.agu.org/?uri=/journals/jd/97JD00796.x $\mathrm{ml} \&$ view=article

Avila, A. and F. Roda, 2002. Assessing decadal changes in rainwater alkalinity at a rural Mediterranean site in the Montseny mountains (NE Spain). Atmos. Environ., 36: 2881-2890. DOI: 10.1016/S1352-2310(02)00098-5

Behnert, I., V. Matthias and R. Doerffer, 2007. Aerosol climatology from ground-based measurements for the southern North Sea. Atmos. Res., 84: 201-220. DOI: 10.1016/ j.atmosres.2006.05.006

Bergametti, G., A.L. Dutot, P. Buat-Menard, R. Losno and E. Remoudaki, 1989. Seasonal variability of the elemental composition of atmospheric aerosol particles over the NW Mediterranean. Tellus, 41: 353-361. DOI: $10.1111 /$ j.16000889.1989.tb00314.x

Burton, R.M., H.H. Suh and P. Koutrakis, 1996. Spatial variation in particulate concentrations within metropolitan Philadelphia. Environ. Sci. Techno., 30: 400-407. DOI: $10.1021 / \mathrm{es} 950030 \mathrm{f}$

Camarero, L. and n. J. Catala, 1993. Chemistry of bulk precipitation in the central and Eastern Pyrenees, Northeast Spain. Atmos. Environ., 27: 83-94. DOI: 10.1016/0960-1686(93)90073-8

Chiapello, I., G. Bergametti, L. Gomes and B. Chatenet, 1995. An additional low layer transport of Sahelian and Saharan dust over the north-eastern tropical Atlantic. Geophys. Res. Lette., 22: 3191-3194. DOI: 10.1029/95GL03313 
Coude, G.G., P. Rognon, G. Bergametti and L. Gomes, 1987. Saharan dust over Fuerteventura Island (Canaries), Chemical and mineralogical characteristics, air mass trajectories and probable sources. J. Geophys. Res., 92: 9753-9771. DOI: 10.1029/JD092iD08p09753

Dayan, U., J. Heffter, J. Miller and G. Gutman, 1991. Dust intrusion events into the Mediterranean Basin. J. Applied Meteorol., 30: 1185-1199. DOI: 10.1175/15200450(1991)030<1185:DIEITM $>2.0 . \mathrm{CO} ; 2$

Dayan, U., Levy, I., 2005. The influence of seasonal meteorological conditions and atmospheric circulation types on PM10 and visibility in TelAviv. J. Applied Meteorol., 44: 606-619. ISSN: 0894-8763

Dentener, F.J., G.R. Carmichael, Y. Zhang, J. Leleieveld and et al., 1996. Role of mineral aerosols as a reactive surface in the global troposphere. J. Geophys. Res., 101: 22869-22889. DOI: 10.1029/96JD01818

Draxler, R.R. and G.D. Rolph, 2003. HYSPLIT (HYbrid Single-Particle Lagrangian Integrated Trajectory) Model Access via NOAA ARL READY Website. NOAA Air Resources Laboratory, Silver Spring, http://www.arl.noaa.gov/ready/hysplit4.html

Erel, Y., A.B. Kalderon, U. Dayan and A. Sandler, 2007. European atmospheric pollution imported by cooler air masses to the Eastern Mediterranean during the summer. Environ. Sci. Tech., 41: 5198-5203. DOI: 10.1021/es062247n

Erel, Y., U. Dayan, R. Rabi, Y. Rudich and et al., 2006. Transport boundary transport of pollutants by atmospheric mineral dust. Environ. Sci. Tech., 40: 2996-3005.

http://www.ncbi.nlm.nih.gov/pubmed/16719103

Escudero, M., S. Castillo, X. Querol, A. Avila and et al., 2005. Wet and dry African dust episodes over Eastern Spain. J. Geophys. Res., 110: (D18S08) 10.1029. DOI: 10.1029/2004JD004731

Escudero, M., X. Querol, A.A. Vila and E. Cuevas, 2007a. Origin of the exceedances of the European daily PM limit value in regional background areas of Spain. Atmos. Environ., 41: 730-744. DOI: 10.1016/j.atmosenv.2006.09.014

Escudero, M., X. Querol, J. Pey, A. Alastuey and et al., 2007b. Amethodology for the quantification of the net African dust load in air quality monitoring networks. Atmos. Environ., 41: 5516-5524. DOI: 10.1016/j.atmosenv.2007.04.047

Falkowski, P.G., R.T. Barber and V. Smetacek, 1998. Biogeochemical controls and feedbacks on ocean primary production. Science, 281: 200-206. DOI: 10.1126/science. 281.5374 .200
Fung, I., S. Meyn, I. Tegen, S.C. Doney and J. John et al., 2000. Iron supply and demand in the upper ocean. Global Biogeochem. Cycles, 14: 281-295. DOI: 10.1029/1999GB900059

Ganor, E. and Y. Mamane, 1982. Transport of Saharan dust across the eastern Mediterranean. Atmos. Environ., 16: 581-587. DOI: 10.1016/0004-6981(82)90167-6

George H., Miley, H. Hora, F. Osman and Y. Yang et al., 2005. Low cost long distance detector for explosives and chemical analysis by iec application. Am. J. Applied Sci., 2: 1529-1532. DOI: $10.3844 / .2005 .1529 .1532$

Geraopoulos, E., G. Kouvarakis, M. Vrekoussis and M. Kanakidou, 2005. Ozone variability in the marine boundary layer of the Eastern Mediterranean based on 7-year observations. J. Geophys. Res., 110: D15309, 12. DOI: 10.1029/2005JD005991

Gerasopoulos, E., G. Kouvarakis, P. Babasakalis and M. Vrekoussis, 2006. Origin and variability of Particulate Matter $\left(\mathrm{PM}_{10}\right)$ mass concentrations over the Eastern Mediterranean. Atmos. Environ., 40: 4679-4690. DOI: 10.1016/j.atmosenv.2006.04.020

Guerzoni, S. and R. Chester, 1996. The Impact of the Desert Dust across the Mediterranean. Kluwer Academic Publishers, Norwell, MA, pp: 389. http://books.google.com.pk/books?id=7vOJ919uwr $\mathrm{oC} \&$ printsec $=$ frontcover\&dq $=$ The + Impact + of + the + Desert+Dust+across+the+Mediterranean\&hl=en \&ei=PZkMTbfNE4PvsgbYx9DZDA\&sa=X\&oi $=\mathrm{b}$ ook_result\&ct $=$ result\&resnum $=1 \&$ ved $=0$ CCQQ6A EwÄA\#

Harrison, R.M., D.J.T. Smith and L. Luhana, 1996. Source apportionment of atmospheric polycyclic aromatic hydrocarbons collected from an urban location in Birmingham, UK. Environ. Sci. Technol., 130: 825-832. DOI: 10.1021/es950252ds

Hutchison, L.M., 1996. Investigation of PMloS Found in the Urban Environment and Human Lungs. M. Phil Thesis, University of Wales, Cardiff.

IPCC. Climate Change, 2007. The Physical Science Basis. Contribution of Working Group I to the Fourth Assessment Report of the IPCC. hardback, 9780521 70596-7 Paperback). ISBN: 9780521 88009-1

Levin, Z., E. Ganor and V. Gladstein, 1996. The effects of desert particles coated with sulfate on rain formation in the Eastern Mediterranean. J. Applied Meteoro., 35: 1151-1523. DOI: 10.1175/15200450(1996)035<1511:TEODPC > 2.0.CO;2

Maenhaut, W., F. Francois, J. Cafmeyer and O. Okunade, 1996. Size-fractionated aerosol composition at Gent, Belgium. Nucl. Instrum. Meth. Phys. B., 109: 476-481. DOI: 10.1016/0168583X(95)00954-X 
Moreno, T., Gibbons, W., Jones, T., Richards, R., 2003. The geology of ambient aerosols: characterising urban and rural/coastal silicate PM10-2.5 and PM2.5using high-volume cascade collection and scanning electron microscopy. Atmos. Environ., $37 . \quad 4265-4276$. DOI: 10.1016/S13522310(03)00534-X

Moreno, T., Querol, X., Castillo, S., Alastuey, A., Cuevas, E., Herrmann, L., Mounkaila, M., Elvira, J., Gibbons, W., 2006. Geochemical variations in aeolian mineral particles from the Sahara-Sahel dust corridor. Chemosphere, 65: 261-270. DOI: 10.1016/j.chemosphere.2006.02.052

Pope III C.A., 1989. Respiratory disease associated with community air pollution and a steel millUtahValley. Am. J. Pub. Health, 79: 623-628. http:/www.ncbi.nlm.nih.gov/pmc/articles/PMC134 9506/

Quality of Urban Air Review Group, 1996. Airborne Particulate Matter in the United Kingdom. Birmingham: University of Birmingham Quality of Urban Air Review Group. Royal Commission on Environmental Pollution (1994) Transport and the Environment, 18th repor, London, HMSO. ISBN: 0239520771

Rahoma, U.A., 2010. Evaluation of aerosol particle size at high polluted region in the world using direct solar radiation measurements: Helwan as a case region. Am. J. Environ. Sci., 6: 159-163, 2010. DOI: 10.3844 ajessp.2010.159.163

Rahoma, U.A. and A.H. Hassan, 2010. Estimate of aerosol optical depth using broadband direct normal observations at highest polluted area in the world. Am. J. Applied Sci., 7: 647-655. DOI: 10.3844/ajassp.2010.647.655
Rasheed, M.A.Q. and Jamhour, 2005. Preparation and characterization of hybrid organic-inorganic composite material: polymerization of maminobenzoic acid-intercalated into zn/al-layered double hydroxides. Am. J. Applied Sci., 2: 1028-1031. DOI: $10.3844 / .2005 .1028 .103$

Sonibare, J.A., F.A. Akeredolu, O. Osibanjo and I. Latinwo, 2005. ED-XRF Analysis of total suspended particulates from enamelware manufacturing industry. Am. J. Applied Sci., 2: 573-578. DOI: 10.3844/.2005.573.578

Warren Spring Laboratory, 1994. Air Pollution in the UK 1992-93. Warren Spring Laboratory, Hertfordshire.

Watts, R., L. Cupitt and R. Zweidinger, 1988. Mutagenicity of organics associated with $\mathrm{PM}_{2.5}$ and $\mathrm{PM}_{10} \mathrm{HiVol}$ particles from a wood smoke impacted residential area. EPA/APCA Measurement of Toxic and Related Air Pollution. Int Symp, pp: 879-886.

Win, Y.F., S.G. Teoh, M.R. Vikneswaran, M.Y. Chan and S.T. Ha, et al., 2010. Synthesis and characterization of organotin(iv) complexes derived of 2-amino-5-nitrobenzoic acid: in vitro antibacterial screening activity. Am. J. Applied Sci., 7: 886-891. DOI: 10.3844/.2010.886.891

USEPA., 1996. Air quality criteria for particulate matter. Volume I. US Environmental Protection Agency, Research Triangle Park, NC. EPA/600/P95/001aF 